THE JESUITS 



\section{The Jesuits}

A HISTORY

\section{MARKUS FRIEDRICH}

TRANSLATED BY

JOHN NOËL DILLON 
English translation and editorial apparatus copyright (C) 2022 by Princeton University Press.

This is a translation of Die Jesuiten: Aufstieg, Niedergang, Neubeginn by Markus Friedrich, copyright (C) 2016 by Piper Verlag GmbH, München/Berlin

Princeton University Press is committed to the protection of copyright and the intellectual property our authors entrust to us. Copyright promotes the progress and integrity of knowledge. Thank you for supporting free speech and the global exchange of ideas by purchasing an authorized edition of this book. If you wish to reproduce or distribute any part of it in any form, please obtain permission.

Requests for permission to reproduce material from this work should be sent to permissions@press.princeton.edu

Published by Princeton University Press

41 William Street, Princeton, New Jersey o8540

6 Oxford Street, Woodstock, Oxfordshire OX20 1TR

press.princeton.edu

All Rights Reserved

Library of Congress Cataloging-in-Publication Data

Names: Friedrich, Markus, author. | Dillon, John Noël, translator.

Title: The Jesuits : a history / Markus Friedrich ; translated by John

Noël Dillon.

Other titles: Jesuiten. English

Description: Princeton : Princeton University Press, [2022] | Includes

bibliographical references and index.

Identifiers: LCCN 2021012468 (print) | LCCN 2021012469 (ebook) |

ISBN 9780691180120 (hardback) | ISBN 9780691226194 (ebook)

Subjects: LCSH: Jesuits—History.

Classification: LCC BX $3702.3 . F_{7513} 2022$ (print) | LCC BX 3702.3 (ebook) |

DDC $271 / .53$ - dc23

LC record available at https://lccn.loc.gov/2021012468

LC ebook record available at https://lccn.loc.gov/2021012469

British Library Cataloging-in-Publication Data is available

Editorial: Ben Tate, Josh Drake

Jacket Design: Karl Spurzem

Production: Danielle Amatucci

Publicity: Maria Whelan, Carmen Jimenez

Jacket art: St. Ignatius of Loyola before Pope Paul III. Anonymous, 16th century. Scala / Art Resource, NY

This book has been composed in Arno.

Printed on acid-free paper. $\infty$

Printed in the United States of America

$\begin{array}{llllllllll}10 & 9 & 8 & 7 & 6 & 5 & 4 & 3 & 2 & 1\end{array}$ 
For Frieda 
